\author{
TERRITDRY OF ALABKA \\ DEPARTMENT DF MINES \\ JUNEAU, ALASKA
}

November 20,1952

\title{
ITINGRARY RKPORT
}

TO:

Phil R. Holdsworth, Commissioner of Mines

FROM:

James A. Willians, Associate Miaing Engineer

SUBJECT:

Fleld trip made by Robert $\mathrm{H}$. Saunders and James $A$. Hilliams through the Fal rbenks, Circle, Cape Norne and Valdez Precincts, July 21 to September 2, 1952

Robert $B$. Saunders anả James A. Williame, Associate Mining Iligineers, mede the abovo trip for the chtef purpose of engaging in geophysicel exploration for the U. S. Tin Corporation at Lost River on the Seward Peninsula in an effort to locate granite intrasives in the limestone which ore pert of the mineralization control in that orea. Magnetic and earth registivity methods were used. Side trips were made to the oircle Diatrict placer operations, the Brooks Mountain zeunerlte property, and two active mining operations in the vicinity of Nome. An eorth resistivity survey was made at the Creighton mine, vicintty of Fairbanks, and a trip was made to Prince William Sound to examine two copper prospecto of Dan Fitzpetrick in Unakwlk Inlet and the Four-in-Ono copper prospect near the head of Miners R1ver. Thts last property was not reached. Den Jones, Ingineer-Assayer at Nome, accompenied Saunders and Williems while on the Seward Penineula.

July 21: Junequ to Fatrbanks via Pan American Airlines. Joined Saunders at Foírbanks.

July 22: Immedietely upon arrival at Fairbanks, it wes learned that the Comrassioner of Mines' recent telegram to the Department personnel at college had not been recelved and that the death of thagene Swendsen, nozzleman for the U. S. Smelting, Refining, and Mining Company, had not been Investigated as requegted in the telegram. Investigation mas made, therefore, on this date ond the report written and sent to Juneau shortly afterwards.

July 23-29: Spent in becomtng familiar w1 th the eerth resistivity equipment ond field-checklng it with the help of Irs. Fivey and Heller of the Geophysical Institute at College. The the two men spent considerable time and effort in finding the solution to the 
proper manner of operating the geoscope, (the operating ingtructiong and wing diagram were migaing) and then in linstructing and working with Seunders and the writer in the theory and actual operation of the instmiment. They wore extrewely holpful, and by their belp mach time was saved and knowledge acquired. Acknowledgment and apprectetion are due them for their wiling asaistance.

Attended a promotional meeting one evening and listened to Chuck Abbot and Larry Giddons trying to sell otock in a ocheolite mining venture of Frikson Plecers, Inc. Their meln seling potat wes a novel placer mining machlne that they intend to butid, and the money that they were trying toraloe was intended for a matching fund for a DWEA loan for exploration purposes out of whlch would como the cost of constructing the machine. Thus, the money from the stock they were selling was merely an investment in the prospecting of the creeks they clain to own of control on the Seward Penineula. It was learned later that most of their ground was held merely on verbal agreements wh the owners. They were using USGS reports on past production of the general aree concerned a proof that the scheelite is there, but they actually know practioally nothing of the anount per yard or totel yardage.

return.

$$
\text { July 30-31: Fatrbanks to Circle Mining Distriet and }
$$

In company with fiarl Beigtiine, Dean of the school of Mines, the plecer operations of the Circle Diotrict were inspected and mining conditions noted. School of Mines transportation was furatshed. Saunders collected the information on this trip and will write the report on the Circle Distict. Operations visited were those of John Frasca on Gagle Creek, Beine Carsteng on Portage Creek, Jens Landlow on Switch Creek, Bob Wilkinson on Miller Creek, the Wrede bxothers on Independence Creek, and the Berry Dreäging Corpany on Maramoth Creek. An attermot to reack the Mury Anderson operation on Porcupine creek falled because of bad road conditions. Fairbanks District operations visited on the way to and fron the Circle District were those of Bob Watkins on Frat th Creak, Mante Olson on Holf Creek, Strom Mining Compang on Chetham Creek, and the Creighton gold lode mine on Pedro Dome.

While in the Circle District, met Poul Bittner, an active prospector who had just come fron the Rampart District where he reported he had found what appearad to be a large deposit of Ilment te and wented the Department to help htm find a buyer for it. Ho had steked six claims there. The sesspies he had taken resembled poilomelane mol'e than ilmente, however, and this opinton was conflrmed upon aubitting it to the college Assayer for analysis. 


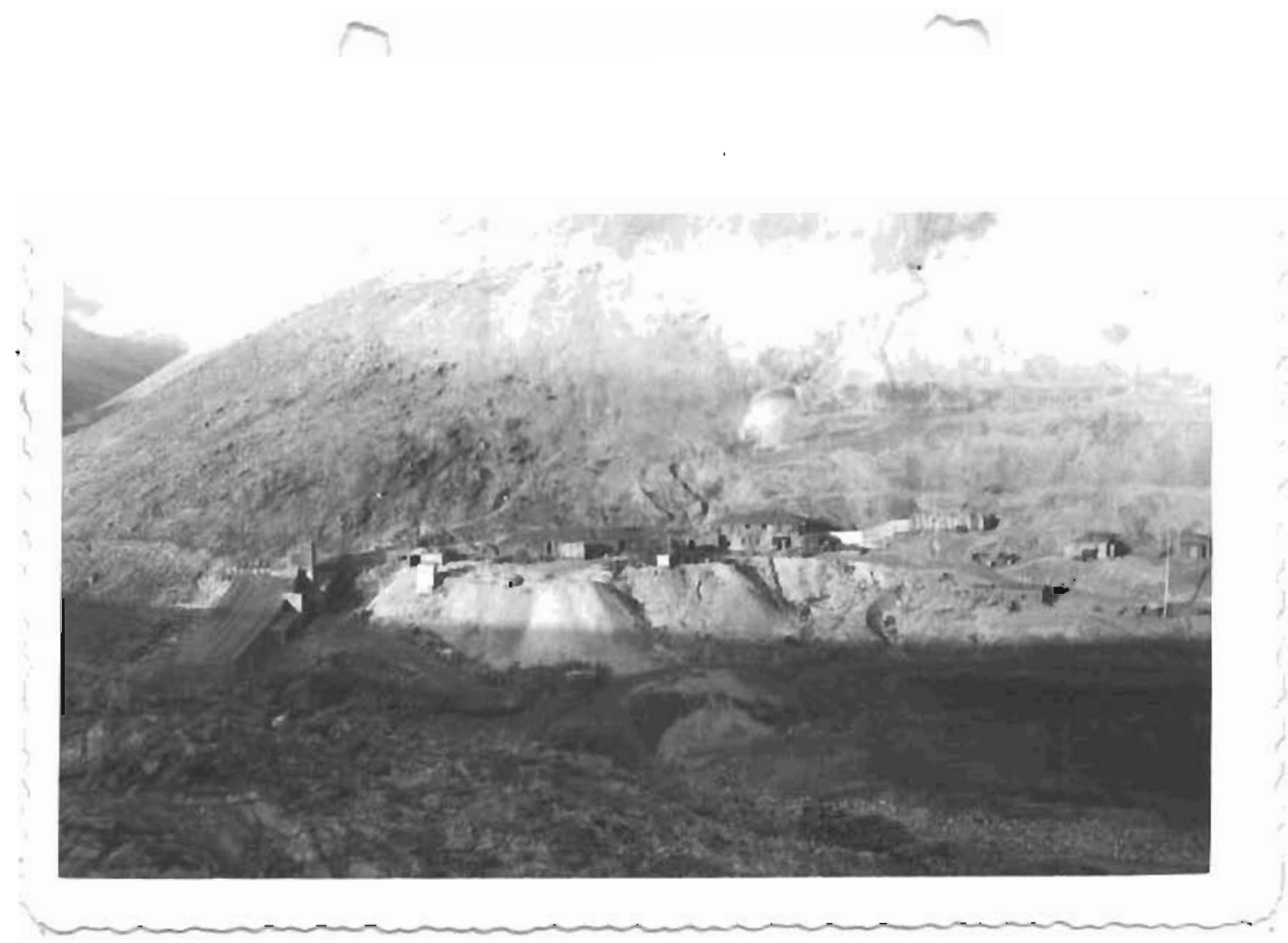

Fture 1. U. S. Tin Corporation, Lost River.

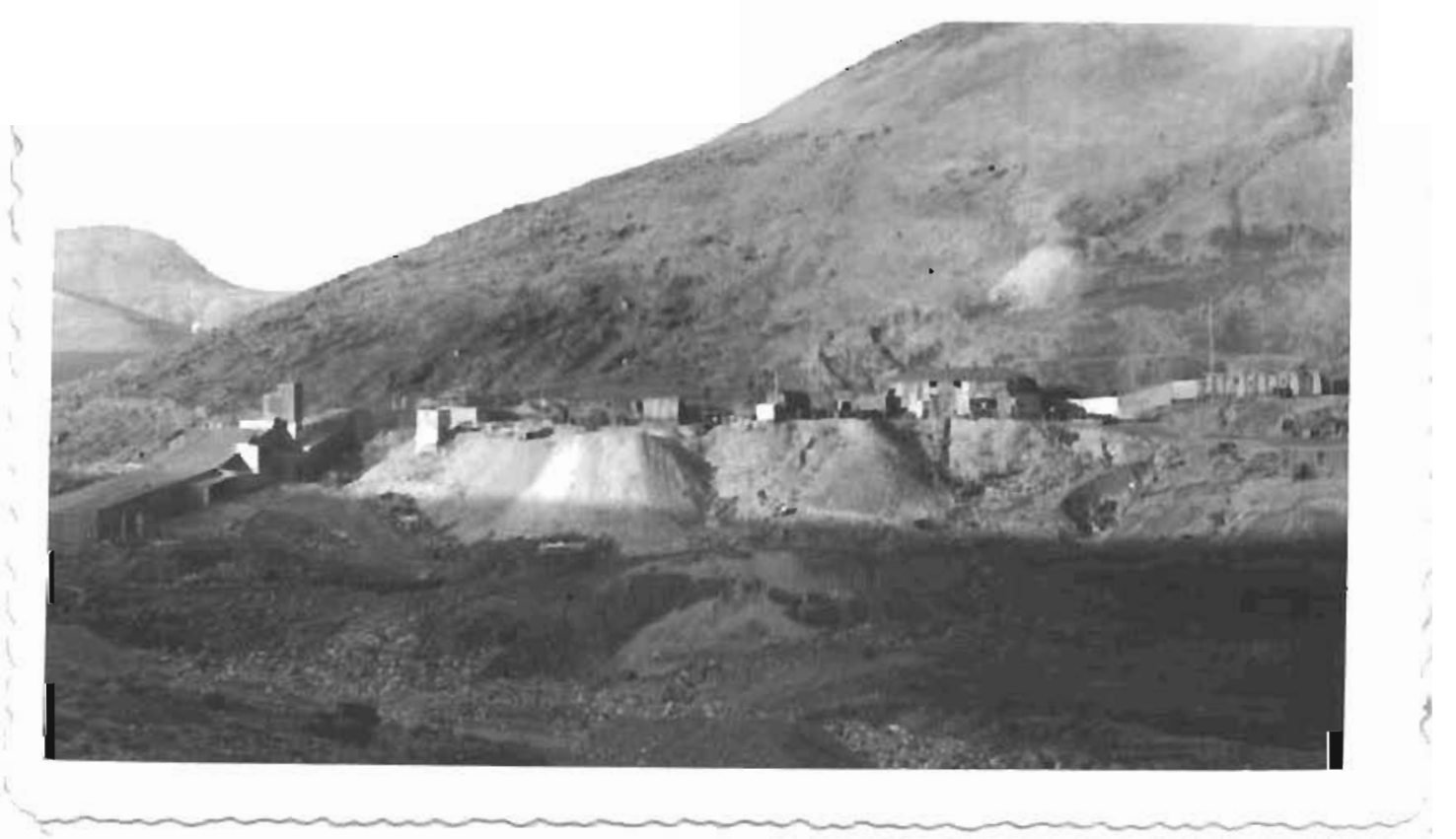

Flgure 2. Another viow of U. S. Pin Corporation. Cassterite Creek in foregrouni. 


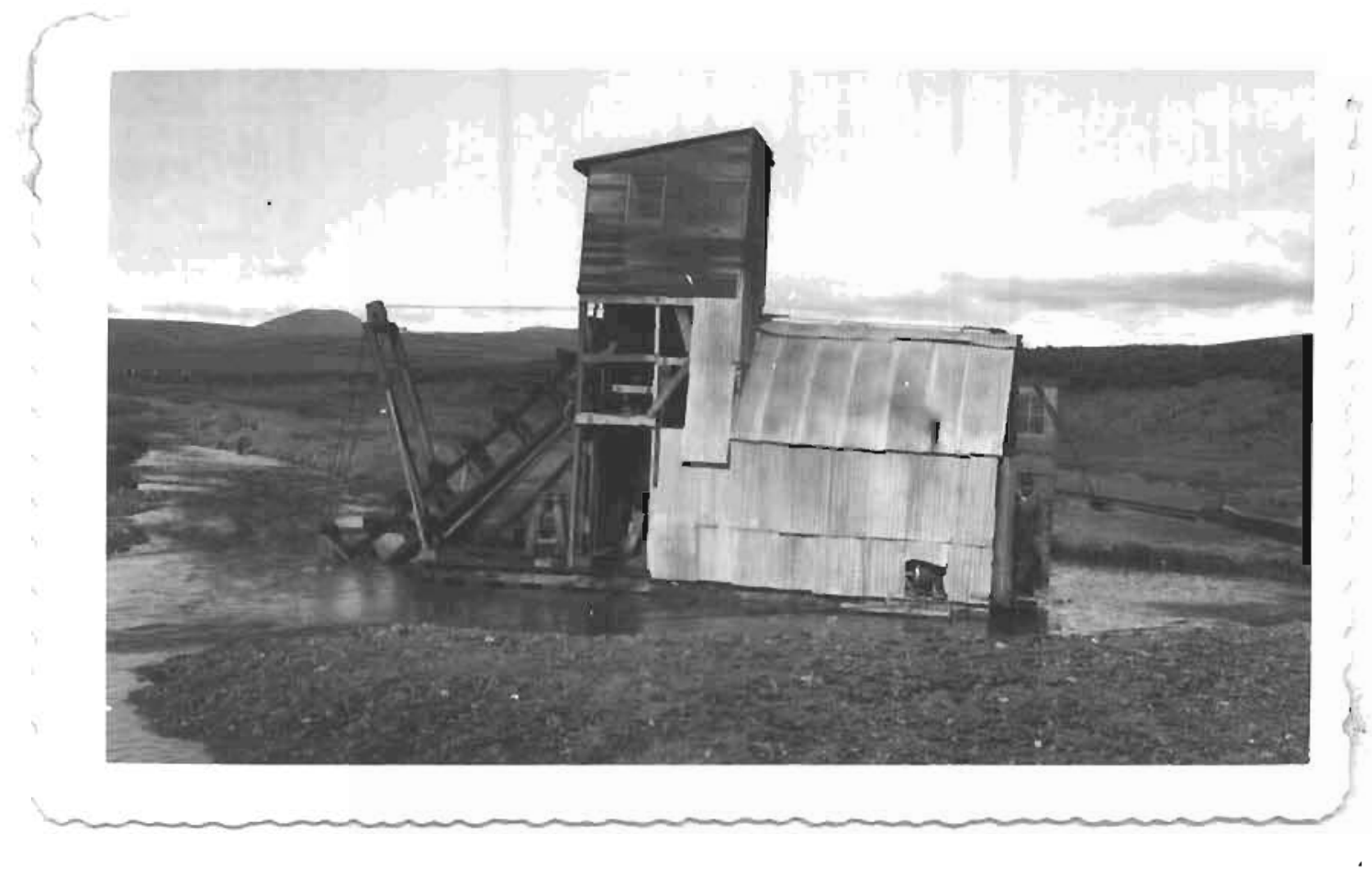

Tigure 3. Homerade dredge of Kougarok Freight and Wining Corpeny. For e1ze, note man on stern deck. 
Bittner reported the deposit to be on a plateau of about three thousand feet elevation at the heads of Grante, Allen and Rock Creeks and Just south of Baldry Mountain. It 18 reportediy in a zone of brocclated linestone and becoming massive in open spots. A zone of float is six to geven husared feet wide and he believes there are at least three ghegr zones with whtch the deposit is aosociated. In view of the increasing denand for manganese, this could posetbly be a project for future investigation by the Department.

Auguet 1, Final preparations for the trip to Lost Biver on the Seward Ponineula.

George Hellertch, Menager of the Johnson Dreaging Corrpeny, $43^{-10}$ Caribou Creek dredging operations, contacted Saunders and the writer with a request for on examation and report with recoinendations on his zeunerite property on Brooks Mountain, which is just a few miles from lost RIver. The USGS Trace klements men have exantued and sampled the prospect, but hir. Hellerich expressed dissatiafaction with their work. The other half-owner of this property is Dr. Kennedy of Nome, but the partnership wishes Dr. Kennedy's name kept confidential. Actually, Dr. Kennedy was the original discoverer. The exemination was egreed upon.

Augugt 2: Fairbanks to Kotzebue ria Wien Alaska Airlines. Held at Kotzebue beceuse of mechenical trouble.

Auguat 3 it Kotzebue. Mechanical trouble and weather.

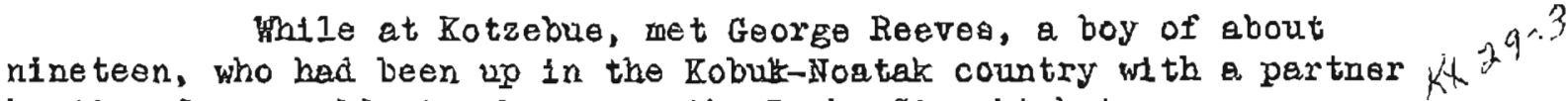
husting for an old wine known as the Iucky Six which is on or near a creek of the sarue name. This mine had been worked by his grandfether (also nemed George Reeves) and was reported to be very rich. Becalige of an accioent in which the partner was bally hart, the pair ald not reach the area, but Reever Intends to try again next year. Lucky Six Creek is a tributary to the Noatak River, and can be found on the USGS Bulletin 815 map. It is just south of 12-Mile Creek which parallels the Noatak River, and its head ters are in cull Pass. The mine 18 reporter to be at an elevation of 5000 feet. The geographical coordinates are $155^{\circ} 00^{\prime} \mathrm{W}$ longitade and $67^{\circ} 35^{\circ} \mathrm{N}$ latitude. Reovest address 18303 Velley Street, Kalemazoo, Michigan.

August 4: Fotzebue to Nowe, Rere jolned by Dan Jones, As sayer-Ingtneer stationed there. 
Talked to Dr. Kennedy in the evening about the zeunerite $\therefore-57$ property on Brooks Mountain. He egreed to reet us at a flight strip (he flies hil own plane) at the botton of the mountain on the follow Ing Saturday, the ninth of August, and show us to and arouni the property. Dr. Kennedy told us that the U. S. Sneltine, Refining, and Mintng Cormeny had afened an option contrect wi th them to investigate the property and hed then broken practically every clause in the contract and had finally refused to leave the ground after the explration date until Kennedy and Hellerich had the U. S. Marshal's office serve the company with "papers." The two partiners are both very bitter about their treatment at the hands of the company. They clatm thet one of the chief violations was that the company mined the one len of zeunerite that was know and removed it completely. our later foilure to find a significant amount of zeunerlte would help to bear this out.

Also talked to Gene Mergref, who is associeted with his father, Oscar Margraf in Native B1smuth, Inc., at Cherley Croek. He we interested in having the Department do some geophysical work on their bismuth deposit in an attempt to locate an extension of the bismath mineralization. We told him that it didn't appear to be a good prospect for geophysical work, but that we would give the problen congideration whlle at Lost Biver.

Angust 5: Nome to the U.S. Tin Corporation mine at ${ }_{4}$ H $^{3}-8^{7}$ Lost Biver via Wien Alaska Alrlines. Two trips were necessary wi th a Cessne 170 to trensport the three of us and all tho fleld gear.

Pemberton Killeen and Charles Humel of USGS were at Loet River on tin investigation work. A conference was held with these men and Paul Sorenson, manager of the tin minling operation, as to the best method of procedure on our geophysical exploration. The problem was to locate subsurface grant te domes or cupoles in the Iimes tone country roak, near the contact of which is likely to be the tin mineralization. One of these structures with the attendIng zone of caseiterite has been proven by core arilling by the Bureau of Mineg. It was decided that the most logical procedure or attack would be to min traverses with both themagne tometer and resistivity equipnent over the known grentite atructure and use the anomalies obtained there as a basia for interpretation of anowalies obteined when treversing unknom areas in search of other granite intrisive boaies.

Auguet 6-14: Magnetic and eorth resistivity geophysicel explorg.tion work on the U. S. Tin Corporation property at Iost River.

Lergely beceuse of mine cerm butlilings, equipnent, power Ines, etc. belng located over the coown granite structure, and 
partly because of a deficlency of magnettie th the Eranite, and the existence of permafrost, the attent to establiah a pattern of enowalies with which to judge later work was a failure. The acene of operations was then shifted to a locelisty toward which the granite dome appeared to trend. No reaults were obtained there, either, that could be interpreted to indice,te the presence of a granite dome beneath the limestone. Accordingly, the project was abandoned. The areas under investigation were mapped by plane table. A full report of the geophysical work done complete with maps and profiles of the traverses will be prepared by Saunders and Hilliams at a later date. Mr. Sorenson specificelly requested a copy of the report as evidence to show that ground magnetic and earth resistivity methods hod been attempted and proved to be velueless in the search for structures likely to carry tin mineraligation in that area.

Further conferences were held concerning posslbtlities of other types of geophystcal exploretion that might poselbly be applicable to the problem at Lost RIver, inclualine onefiscussion with S. H. Loratin and Al Ransome of the Bureall of Mines. Mr. Killeen was of the opinton that reismic work would be useless beceuse of the fact that the soft kaolin-like material at the contact would not properly reflect the shock waves. Some of the persous involved favored the laee of atrborne magnetometer work. The writer hesitates to accept this view because of the nature of the Grent te and the extremely difficult and hazardous flying conditione in that locality. It is possible, though, that aerial megnettc work rifiht outlino general areas of grant te intrusions. It 18 recomended thet an authority on airborne magnetoweter work be conswlted on this problem.

Concerning the operation of the mine and rill at the time of the writer's visit, the following facts were observed and noted. A crew of sixty men were employed, but it was reported that this would tesper off to about forty-five during the winter. By far the largest nurber of men were employed on the aurface. The chief mining problem was in stoping the twelve-foot mineralized dike which dips at seventy degrees. Thls dike carries the tin and tungsten, and the gangue resembles a sort kaolin. The walls stand well. The ore at first sterted to fall and $\mathrm{B}$ tope itself when undercut, and it was thought that it would continue to do so without rouch further drilling and blasting. Thts assumption turned out to be erroneous. The meterial is too hard to break by 1 ta own weight, yet too soft to be safe to work underneath becelse of the Iikelthood of frequent fails. Further, slace there are no trees on the Seward Peninsula, the cost of timbering the stopes would be probtbitive to the operation. The nature of the ore ig auch that it packs and ireezes if left broken very long in the stope, so shrinkage stoplng cannot be employed. The ldea was conceived of cutting a diamond drill stetion within the dike and ariling long dianond drili holes up to 150 feet 
lengthwise in the dike, loading them and blasting down large tonnages at one stroke. Thts plan failed because of the fact that when the keolin was ground by the bit and wot, it formed a gunm gubstance that blocked the hole around the bit. preventing the weter from carryIng out the sludge, or cuttinge, although ter pressures up to 135 pounds per square inch were used. Thus, the diamond drill bits could not penetrate more than a few inches. Both core and plug bits were tried.

Pneumatic bammer-type drill bits also plugged quickly if the water hole was in the center of the bit, but it was found that the type with the hole in the side of the ateel just back of the bit worked with fair success. The plan adopted just before tho wrtter's deperture was that of cutting drilling stationg in the footwald. fensing out long holes with Leynors, using the latter type bit and sectional steel. When the writer left the property, the blacisan th was raking the sectional steel, as there was none on the property at that tine. Production to that date was four to five hundred tons of ore out of the mine and through the mill.

A now haulage way was being arlven in from the surface which will locate the portal nearer the mill. Bhiture development plans call for two drifts to be driven to the grante cupola which is known to carry the flat zone of tin (one to each side) and a third drift to be driven under Cassiterite Creek to the Intereection of the main alke with enother tin-bearing dike on the far side of the creek. The drifte to the granite will be 370 feet below the present havlage level, and the drift to the dike intersection at 200 feet with a second one tentatively planned at 400 feet below the main level if the first one discloseg satisfactory ore. Hoisting is at present by air, but an electric holst has been purchased and will be instaliea.

The miling problems were also being gradually overcome. It was found that the original plan of operating wh thout a clasaifler was not practical, so a Fahrenwald hydraulic classifter had been purchased and arrived at the property just before the writer left. The Jigs did not work satisfactorily and were removed from the circult, and ats or elfint more concentretion table were to be added to the four already insteilled. Two Deisel generator setg were being adied.

Mr. Sorenson atated that the only problems he felt that they could not work out themselves were those of shtpping, transportation and commications.

Safety conditions were noted throughout the mine and mill and were found to be satlsfactory. 
Fitgures 1 and 2 are photos of the main part of the camp. The erea underlatn by the known granite stmacture sterts in the right hand portion of those views.

August 2: Investigated the Brooke Mountain zeunerite property. Travel from Lost River to $3500 k s$ Mountain and return was by foot.

Dr. Kennedy aid not meet us at the fitght strip a

planned, and after an hour's wait we walked on up Brooks Mountain to the property. A sudden rather violent wind and rain storm struck the mountain as we arrived and kept ue from makting a thorough inrestigation. Very little zeunertte is in evidence now, but other radioactive materiel are abundant. The property eppeare promising, but mat be prospected further-preferably drilled--to properly valuate it. It is very likely thet more lenses of zeunerite are beneath the ourface. Jones agreed to return to the property wi th Kennedy before the end of the season when a better oramination would be possible, and then prepare a report on the property.

The owners of the property are trying to interest the United Geophysical Corpany in it through Ted Mathews of Falrbanks, who is an agent for Unt ted Geophyatcel.

Angust 15: Lost River to Nome via Munz Atrways.

August 16: At Nome waiting for the rest of the geophysical equipment to be brought in from Loat River.

Auguat 17: Visited the Big Eurreh Mine, vicinity of Solomon. Travel was by borrowed JSGS Jeep, courtesy of Mr. Killeen.

The Big Hurrah is a gold quartz mine which was a large producer but is not now in production with the exception of the tailings-cyaniding operation wich 18 in progress. Travis $P$. Lane 18 the presldent of the Lane Investment Company that owns the property, and the company is largely a fomlly offair watch hos beld the mine for reny jears. There is mach ore left in the mine tilat runs about $\$ 30$ per ton, according to $\mathrm{Mr}$. Lane, and he has recently discovered some scheelite there also. A sample of concentrate he tested was $0.7 \%$ $W_{3}$. The uaderground workings are getting quite run down and the shaft is difficult and dangerous to descend. Jones accormanied Mr. Lane underground on a short inspection wh th a ranerallght. The intereating feature of the ore is that the gold is in very barrenappearing bull quartz which often runs through the slate in very small stringers or ribbons. The slate contains considerable graphit $\theta$.

When the Big Eurrah was in production, the milliag was simply by stamps and amalgamation, leaving good values in the m112 
tailings. Mr. Lane fairly recently started a cyanidetion operation on the teilings. The crew consists of four men, lncluding Mr. Lene. They bullaoze the tailings into a durm truck, and then dump them into the tanks of which there are four. They are wooden, sixteen leet in diarneter, six feet deep, and hold about forty tons each. One tanic Is emptied of treated tailings and refilled each day so that the time of treatrent is a period of four days, and theproduction rate is forty tong per day. The cyanide oolution is percolated through the toijings in the cyaniding tanks, then goes through the zinc tenks where the gold 1 a precipitated, then goes on down into the solution tanks where the solution is maintained at proper atrength, and from there is pumped back up to the cyaniding takk. Originally, there were about 50,000 tons of tallings, but they were dumped into and beside a creek whlch has washed most of theza away, leaving about 20,000 tons to be cyenided. Mr. Iane reported the value of the tailingB, but he requested that the figure be kept oonfidential within the Deportment.

August 18: Visited the Kougarok Freight and lining $x_{-\infty}=-18$ Company dredge on Buster Creok. Transportation was again by USGS Jeep, courtesy of $\mathrm{KI}$. Killeen. Nome to Flairbanks thet night. Jones remained at Nome.

The Kougerok Freight and Hining Compeny is composed of two partners, Elwer Straub and Earl Towner, both of Noine. They ere operating a small homemade flune-type dredge on Buster Creek (tributery to Home River about elght miles north of Nome) that they personally constructed out of two war surplus Tr-14 International tractors, arill cesings, Quonset hut materials, etc. The dredge is well fabricated and apparently rnechanically sound with the exception of the fact that the one tractor motor of $63 \mathrm{fP}$ belng used at preseat is not quite enough power when the digging becomes difficult. It is one of the finest.pieces of homerade minting equipinent the writer has seen. The bucket chain is made from the tractor tracks with the pads removed and the upper turbler $1 \mathrm{~s}$ simply one of the tractorgl arive sprockets. The buckets are small (about one cubic foot) and taken from an earth excavator. Their veakness is that they break at the back of the bucket where they are bolted to the chain. The bucket ladier and gantry are fabricated out of stxinch drill casing. A depth of eleven feet con be dug ana the rate of exceration is about one yerd per minute. There is one spud which is prectically in the center of the exedge, rather than at the tern. The buckets dump directly into the sluice, there being no trommel screen, and boulders must be knocked off the buckets before reaching there. Flotation is accomplished by oil druns on end below the areoge, and the size of the hull is about fifteen by twenty feet. It can be seen that a dredge like this will have to have shallow ground, easlly washable materisl, and few boulders 
for successful mintag, but these conditions extst at Buster Creok, and the dreage is dolng well. The partners claim to be working ground worth only twenty cents per yerd at present, but hove ground worti up to $\$ 1.00$ upstream that the are moving toward.

Figures 3, 4 and 5 are photos of the dredge.

\section{August 19: At College.}

Talked to Barl Pilgrin about the location of a copper prospect known as the Bour-in-One above Miners Lake in the Prince William sound area which we hoped to examine. He reported this prospect to be at an elevation of ebout 1800 feet near the head of Hiners River and below riuson Glacier. Miners Leke is on the east atde of Unakwik Inlet. Pilgrim stated that he made a report and map of this prospect which should bo in the Juneau files. They have since boen located. Herry Townsend has a.lso visited this prospect.

The writer was contected by Jack Maboe who owns the livkluk Shop in Fairbanks. He would like to be put in touch with any prospector or miner who will cell him interesting Alaskan specimens such as pieces of jade, copper, gold quertz, quartz crystals, cassiterite, cinnabar, etc. He clalms to have a very good market for this type of item in his tourist business. His mailing adaress 1s Bor 667 . Fairoanks.

August 20: Inspected the Alaska Hetals Mining Company's scheelite exploration project at Gilmore Dome.

It had been reported to us that the operation had struck a new formetion and were in need of advice on what step to take next. Upon arrival at Gilmore Dome, we found this information to be erroneous. The program was going einegd as planged and nothtng new or different had been found. Also, we found that men frow the local USGS office, Robert Chapman and Gordon Herrold, were daing the necensary englneering on the project.

An existing adit was being driven further in order to connect of th old workings from which the ore was hoisted in a shaft which was collared on the top of the dorae. Also, it was expected that thys edit would cut through a block of ore. The ore hed not been reached at the tirne of the visit. Two sites had been plcked where showings are good for portels of lower adits to be ariven when the present one 18 fintshed. A diemond drill is on the property but was not being used. It 18 only for the purpose of meintelning contact with the ore when the drifte lest the vetin or formation so thet the orifts could be driven straight. Drifting was to be the 
chlef means of exploration, although dozer trenching was elso being done. Also planned ts the deepening of a dirtet down on Yellow Pup. It is hoped this will create a eource of water which is at present being houled up the hill from a distant source in berrels by truck and pumped to the drill by means of a pump and pressure tank. Placer scheelite prospecting is also planned for the Yellos Pup placer Eround.

Thts operation 1s financed by DMEA funds. The original plan called for the construction of two 25 ton mill which was at first approved and then disapproved and to now pendine upon developments. One of the mills was to be for custom milling for other gcheelite producers in the district. The Aloska Metals Mining Company is corposed of four partaerb! Willtan Birklia, Morrio Rafn, Flmer Stobl and Melvin Anderson, all of Fatrbanks.

A Universal Dredge Conpany compressed-atr locomotive is being used for traming and the care are of the two-ton side dump vartety. The loader to Joy rocker loeder, and the compressor is a Gardner-Denver 5004foot capacity wf th a Caterpillar Deisel engine. The undergrownd equipment wag rather poorly chosen as the locomotive will run only 400 feet whout recharging, and the cars are too long for the sharp turas in the old drift and too high for efficient loading with the loader which was designed for one-ton cars. This equipment can be seen in Figures 6 and 7 . Four men comprised the working crew-two on each of two shifts. They were driving the arift on contract. It is planned to continue the operation through the winter if possible.

A rood problen exists there which will be worse with the approaching winter. The Gilmore creek road was being used, but after the freeze-up, this road will graduelly becowe 1mpassable because of the slaciering of the many small streams which 1 t crosses. Tibe ridge rood wintch connects the carip with the steese Eighway at Cleary Surntt hed been torn up and mede impesseble by tanks and other equipment of the rourth Infentry auring maneuvera in the area. This road should be repaired and kept fice of snow so that it may be used as an access road during the winter. It is suggested that the proper road officials be contacted fo1 assistance and that a request be also eent through proper chennels to the Army and the Fourth Infantry to prevent further damage to the road. It wes reported by Mr. Refin that $\$ 1200$ was appropriated for joed work on the Gilmore Creek road and given to the Road Commigeion. The AFC cletme to have used the money up in repairing and maintaining the road, but the partners say that not that much work has been done and that there should be some money remining. 
August 22, 23, 25: Ferth resistivity work at the Creighton Mine on Peáro Dome.

Charles Lazeration and Vern Jokela are mining at the old Creighton gold lode mine. The gold is in a small steeplydipping quartz vein. The country rock is schist. A fault cuts the vein, and on one side of the fault the vein has never been found. It was thought that perhaps this portion of the vein could be treced and loceted by earth resistivity measurements, and accordIngly, three days were spent in the attempt. The project fatled, largely it is belleved, because of alternating frozen and thewed ground. The electrical difference between frozen and thawed ground is undoubtedly greater than that between quartz and achist. Eowever, It may be that the narrow quartz vein would not have given a sufficlent anomaly in any case. Selinders intends to do a geological mapping project on the Creighton wine this fall or winter and will include the resistivity work in his report.

The Creighton kine is leased from the luane Franklin estate, which is administered by his widow, living in Fairbanks.

Lazerg,tion and Jokele are working partners, dolng the mining themselves and hiring no heip. They dunp their ore until a certain tonnege is reached, then truck it dow to the Cleary HIII Mines mill, where they mill it under an agreement with the cleary Hill management. They pay $\$ 7.00$ per ton for this privilege. Iheir ore rung around $\$ 70$ per ton, it is belleved. Jokeln has only recently. racovered from a broken lag, recelyed from a fall down the shaft, which took ebout two years to mend. Iurlas this time, Iezeration carried on alone to the best of his ability. These two men are good hard-korking hardrock miners of a type that has become all too scarce in the lerritory. They deserve all the help and encouragement that can be given.

August 24: Moved the College Field office equipment and furaiture into the new office quarters which were generously alloted to the Department by the Untversity School of Mines in the new hines Building.

Aucust 27: Fairbanks to Cordova vie Cordove Air Service. Cordova to Goose Bay, Prince Williams Sound, aboard Dan Fitzpatrick's Pishing boat.

August 28: Goose Island to Unakwlk Inlet. Exanined Dan sitzpatrick's two copper prospecto there.

The location of these two prospects as indicated in a ske tch map included in en earlier itinerary report dated July 10, 
1952, 1s erroneous. They ere located as shown in the sketch meps in Figure 8. The prospects were disappointing in that they vere Iow grade, not nearly as extensive as had been reported, and little or no work had been done on them by Fitzpatrick. He had been retelling largely what an earlier locator had told hitm. It is not considered necessary to write a separate report on these two prospects. The two samples that were reportediy assayed at 6 and 8 percent were either amall handplcked specimens, or came from another location.

On the east side of Unakwik on the way up to the nain prospect, on adit was encountered at 250 feet in elevation thet wes driven in a shear zone striking $565^{\circ}$ is and dipping $75^{\circ} \mathrm{s}$. The only minerglization wo, occastonol thin quartz stringers, and radioactivity checks gave negative results.

At 480 feet, a cut was blested as $1 f$ to start an adit in a shear zone which hed the same strike as the lover one, but dipped $85^{\circ} \mathrm{N}$. Small amounts of chalcopyrite were noted here. Radioactivity wes again negative.

The main prospect was found at 900 feet in elevation where a strearn had made a deep narrow cut through a shoar zone and a suall open cut had bean blasted some time ago. The strike of the zone is $565^{\circ}$ E here $8.1 s 0$, and the dip 1 s nearly vertical but slightly to the south. There are brenchlng iractures in the footwell dipping south. Channel sample JW-52-34 was taken here across forty inches of the north atde of the zone. The assay returns on thit s sample show a trace of gold, 1.80 ounces of silver per ton, $1.91 \%$ copper, $0.70 \%$ lead and $1.68 \%$ zine. The total with of the zone is about five feet, but the creek hed cut out some of 1 t. see Fifure 9. The chief mineral is chalcopyrite. This is the only plece in the shear zone where the minerelization showed up well, though it is posible that if the ahear zone were to be well prospected, better watnerelization might show up. The shear can be followed for a long distance. Sitzpatrick was govised to prospect it as far as he could trace it with the possibility in mind of exposing a more extensive area of mineralization. Radioactivity appeared very slightly above normal where the sample was cut.

On the west side of the Unakwik Inlet in a small cove Jugt south of the mouth of SIwash Bay, the other prospect is on the beach and consists of very small mineralized stringers widely soparated in the linestone. Some of these stringers ere veryrich (solid sulfides) but the overall velue vould be low. No tonnage could be developed from what is exposed. Sample JW-52-35 was taken 


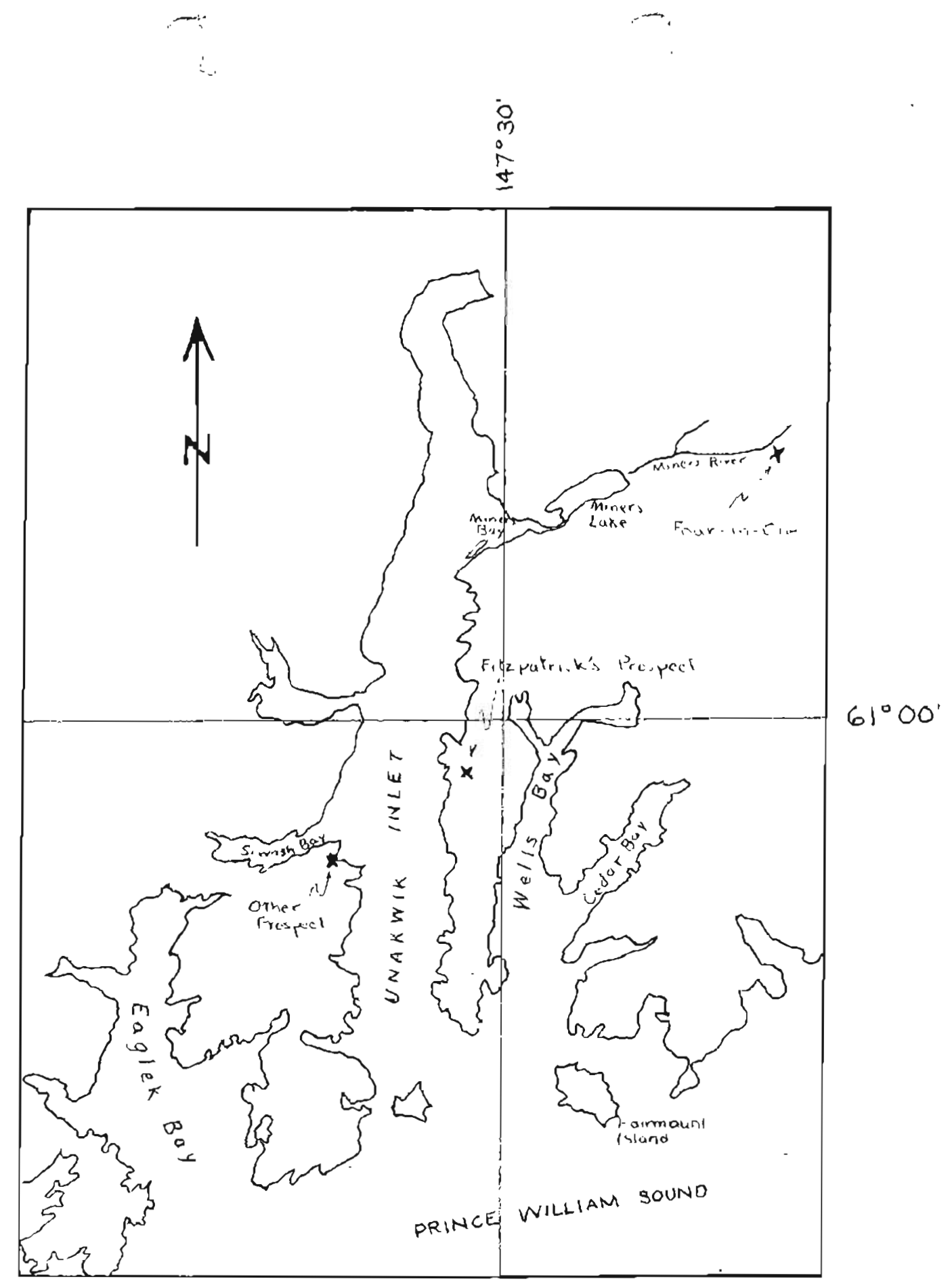

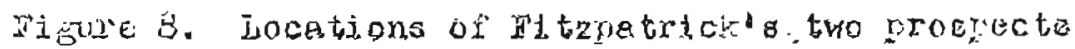

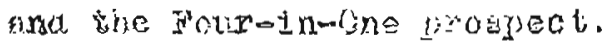

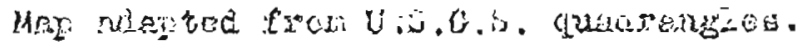

scale: I incis equils" riblos. 
for positive identiflcation, and the College Ascay Office rep rted chalcopyrite, sphalerite, and a trace of lead. It was sueges $3 d$ that a few slabs might be blasted off the faces of the expose rock to $s e \theta$ if the atringers might tend to widen. Radioactivity $b$ is is negative. The above radioactive checke were made with a Deter tron IGG-2 radiation detector.

Auguat 22: Anchored in Miners Bay. Inveatigated a nickel prospect there and made two recomnaissence trips to Miners Lake in preparation for the trip to the Four-in-one copper proppect.

The nickel prospect is on the north side of the entrance to Miners Bay and consistsof about 200 feet of drifts and cross cuts about twenty feet ebove high tide. The workings follow shear zones, but the shears show little mineralization.

It was found by the reconnatssance trips to Miners Lake that the skiff that had been reported to be at the lake was not in safe condition to be used and that wo could not get around the laike on foot within a reasoneble length of time. Therefore, we would have to "Iinell a skiff up the river to the lake (a short atretch of rough water) in order to travel up the lake. It was planned to atart up the river early next morning if the weather was not too bad.

August 30, Fitzpatrick changed bis mind and decided that he did not want to teke his skiff up the river to the lake for fear it was too small and he might lose $1 \mathrm{t}$, so there was nothing to do then but return to Ooriova. It is probable that the trip up Miners River to the prospect would heve ended in failure, anybow, because of the continual bad weather. We looked for an old copper property in cedar Bay on the return trip, but fajled to find it. Arrtred in Corlova late at night just ahead of a storm.

Since it is reported to to a promining prospect, which hes apparently not been well sampled, it is recommended that another and better planned atterpt be made to reach the Four-in-0ne next season. Dominic Vietta of Valdez was reported to have held the property for mony years and may be still holding $i t$.

August 31 - Sept. 1: At Cordova, awalting transportation.

Sept. 2: Cordova to Juneau Vie Pacific Northern Alrliner. Saunderg returned to Falrbanks from Cordova on the firat avallable trensportation.
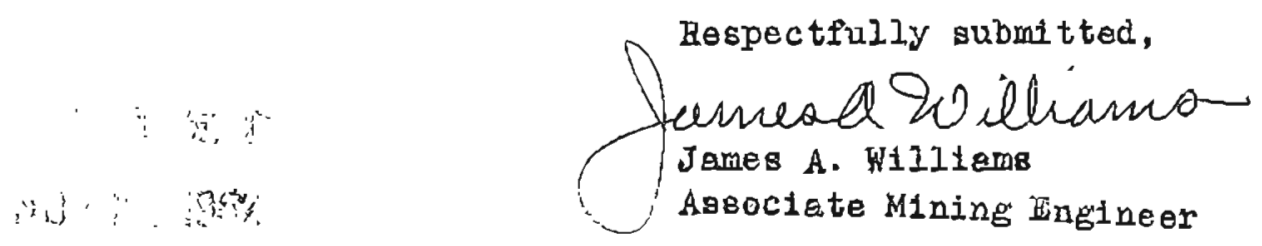


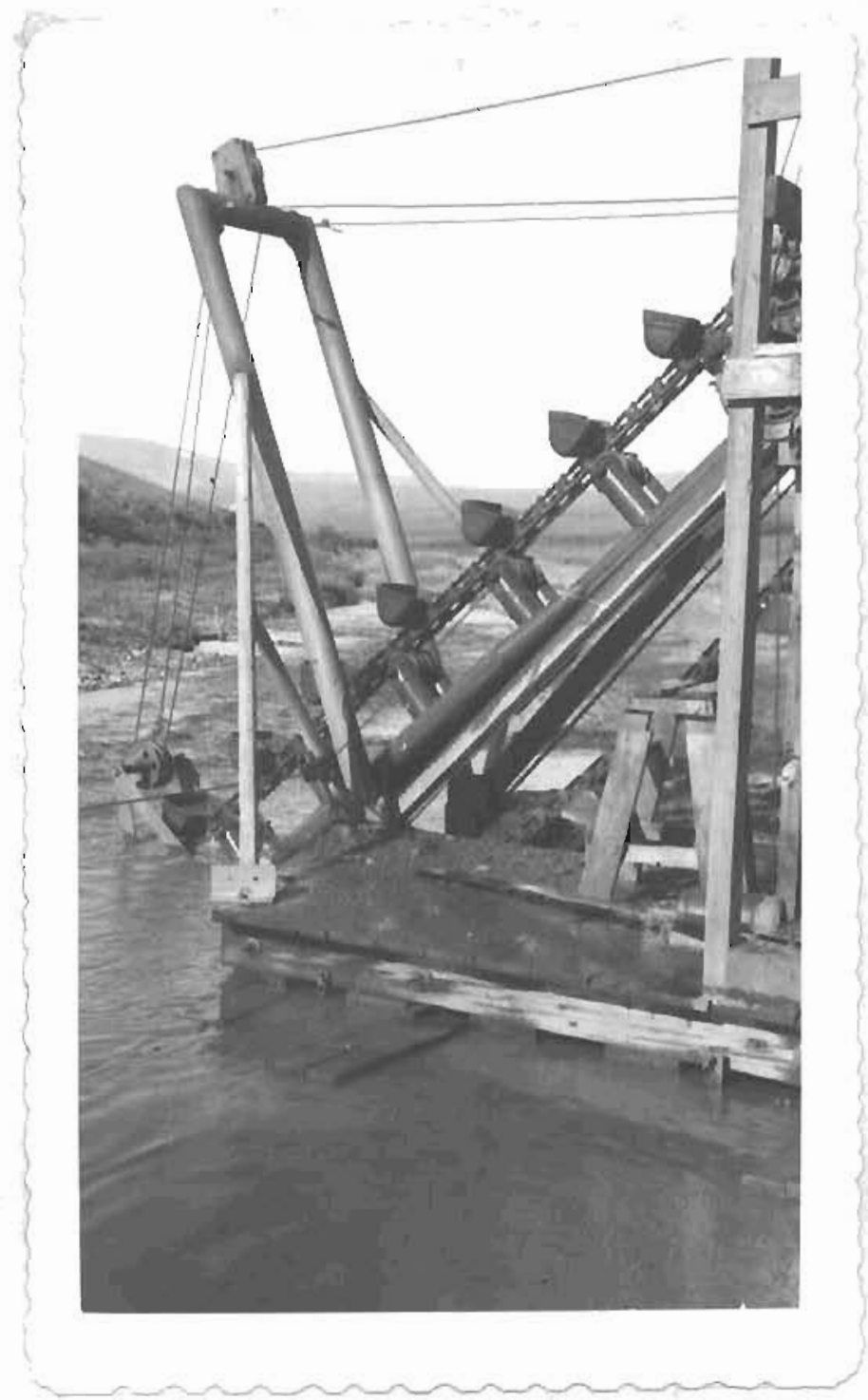

Btgure 4. Bucirat ladder of iougarok Freigit ana Mining Company dredge.

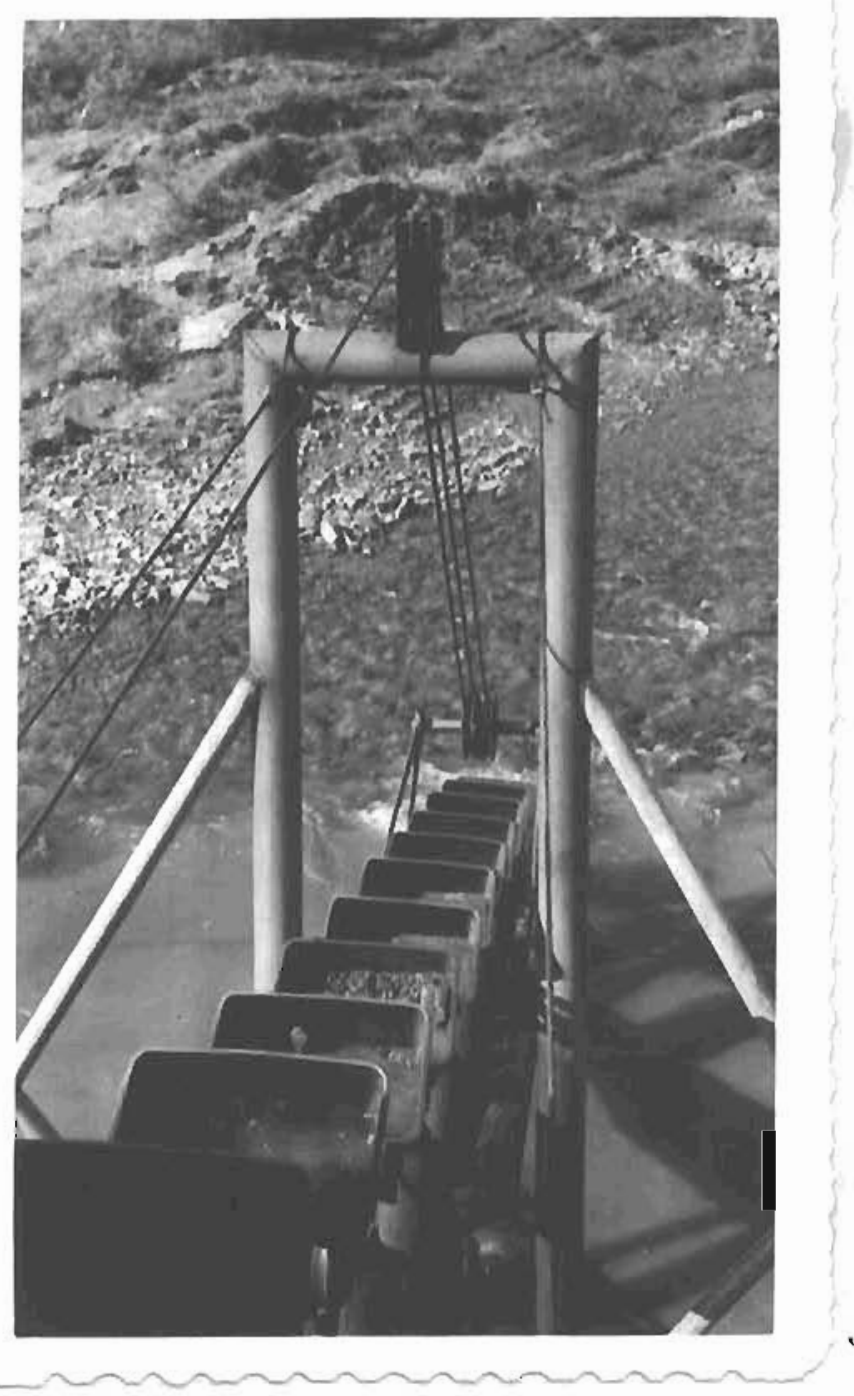

Figure 5. Viow of bucket ladder of homemede aredge from ebove. 


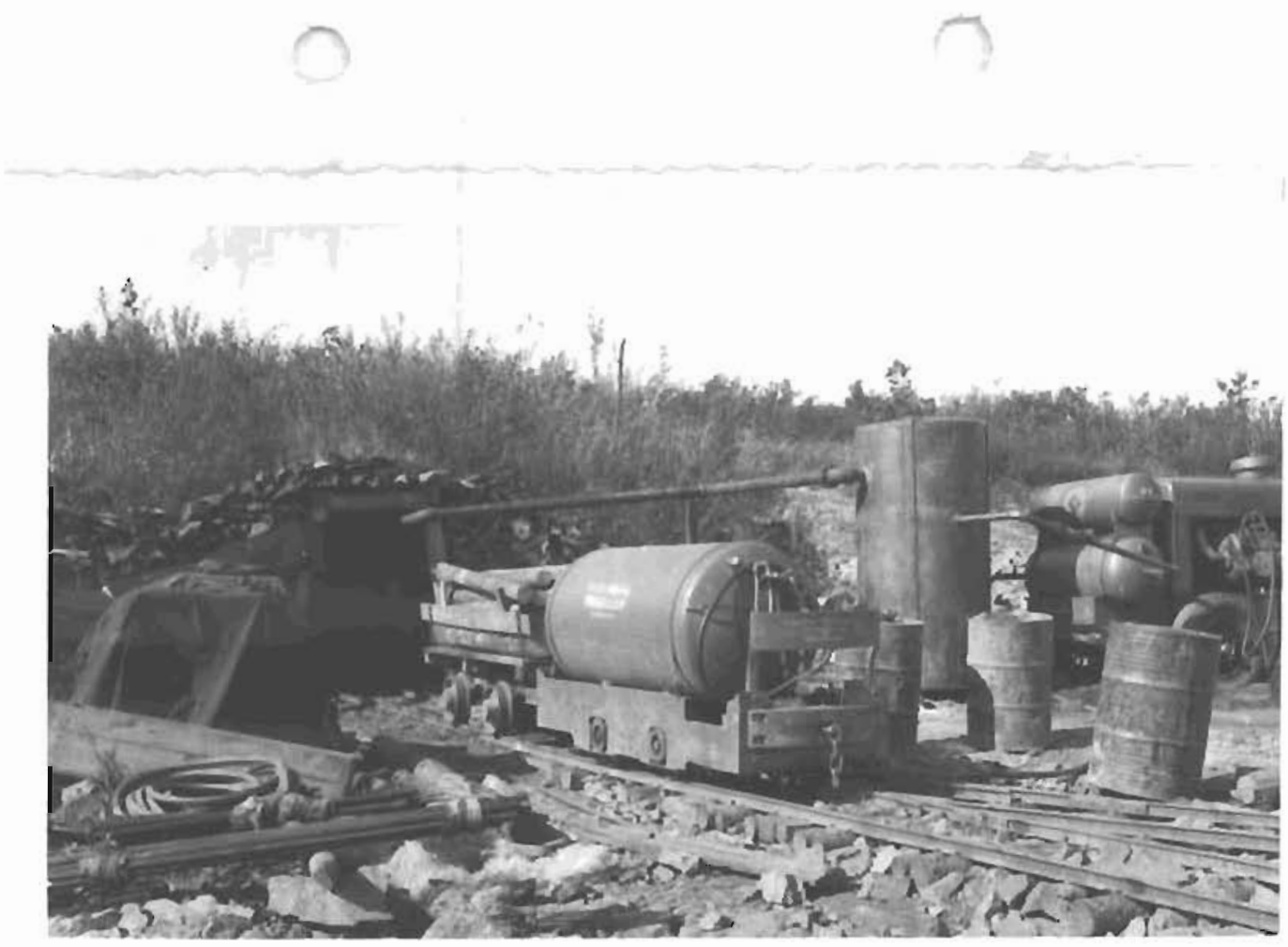

Jigure 6. Alaska Metals Mining Company portel at Gilmore Dome. Compressed air locomotive in foreground.

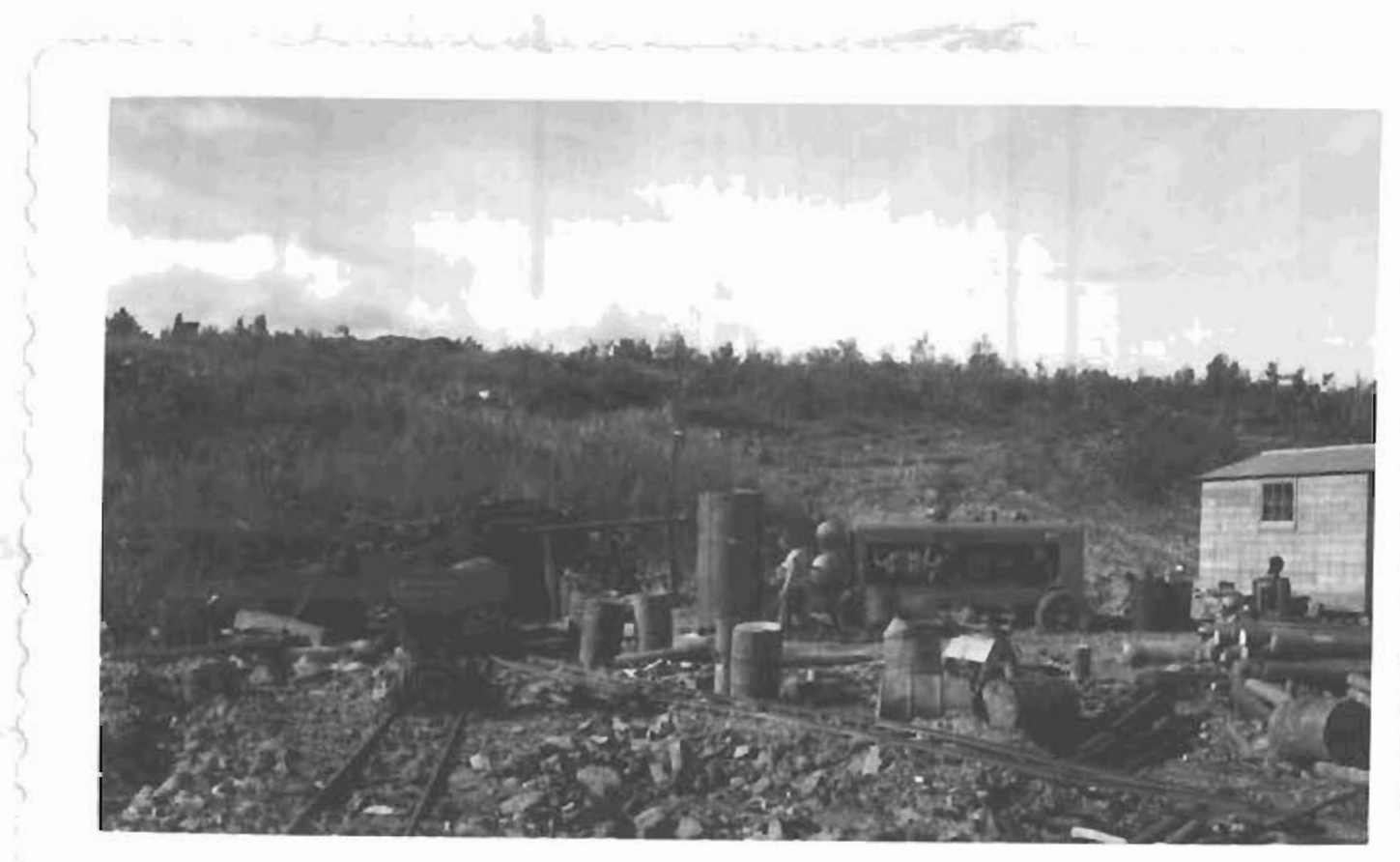

Figure 7. Another view of portal at Gilmore Dome acheelite exploration project. Mine car in foreground. 


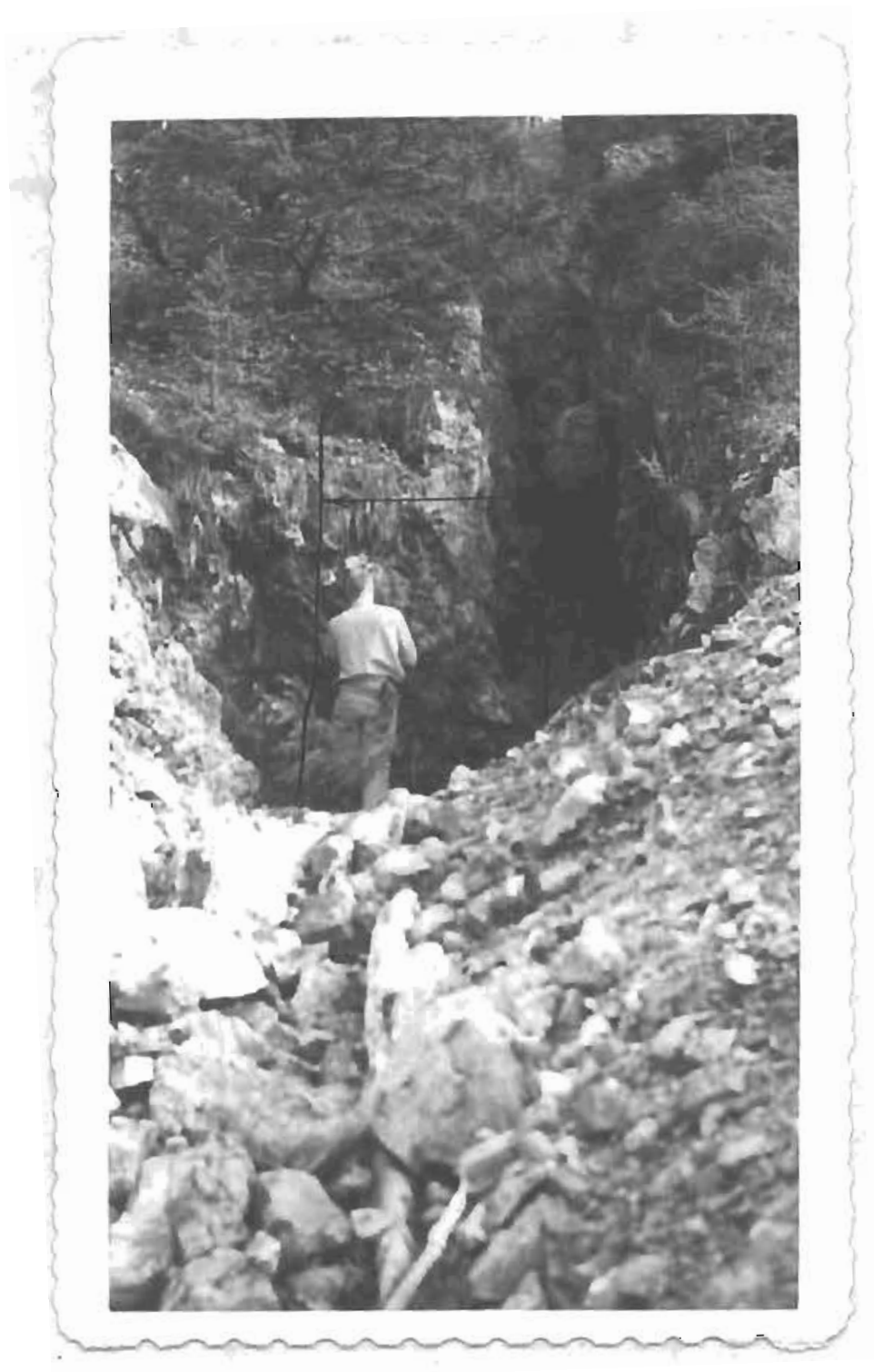

F1 gure 9. Fitzpatrick's main prospoot at Jnekwitk Inlet. Approximate widih of ninerallzed zone showr by laked IInes. 